\title{
Framing for the Heritage Conservation in Malaysia
}

\author{
Karmilah Abdullah, Tan Poh Ling \& Azlan Abdul Rahman
}

To Link this Article: http://dx.doi.org/10.6007/IJARBSS/v11-i11/11606

DOI:10.6007/IJARBSS/v11-i11/11606

Received: 04 September 2021, Revised: 06 October 2021, Accepted: 25 October 2021

Published Online: 20 November 2021

In-Text Citation: (Abdullah et al., 2021)

To Cite this Article: Abdullah, K., Ling, T. P., \& Rahman, A. A. (2021). Framing for the Heritage Conservation in Malaysia. International Journal of Academic Research in Business and Social Sciences, 11(11), 1273-1292.

Copyright: (c) 2021 The Author(s)

Published by Human Resource Management Academic Research Society (www.hrmars.com)

This article is published under the Creative Commons Attribution (CC BY 4.0) license. Anyone may reproduce, distribute, translate and create derivative works of this article (for both commercial and non-commercial purposes), subject to full attribution to the original publication and authors. The full terms of this license may be seen

at: http://creativecommons.org/licences/by/4.0/legalcode

Vol. 11, No. 11, 2021, Pg. $1273-1292$

Full Terms \& Conditions of access and use can be found at http://hrmars.com/index.php/pages/detail/publication-ethics 


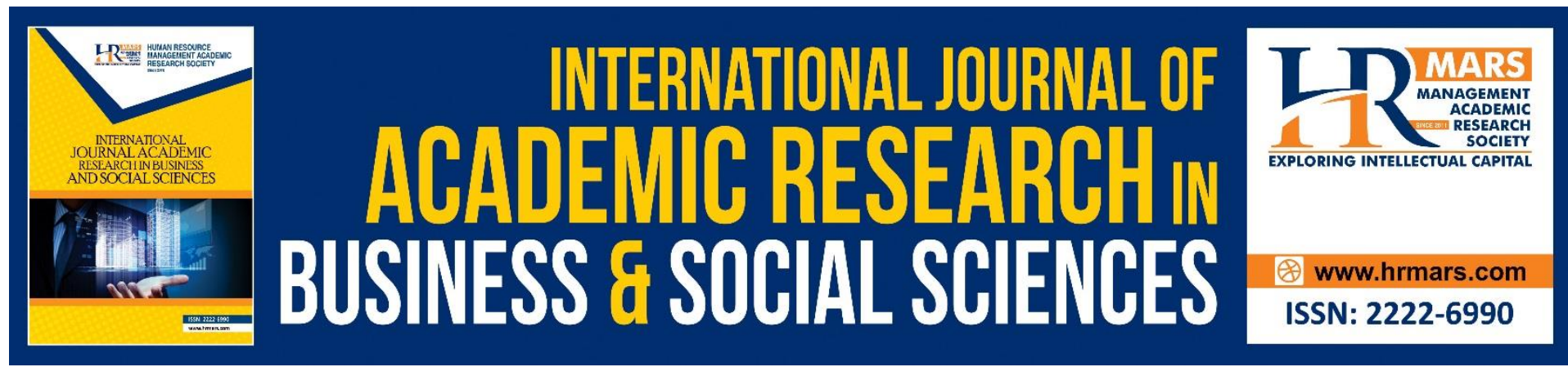

\title{
Framing for the Heritage Conservation in Malaysia
}

\author{
Karmilah Abdullah ${ }^{1}$, Tan Poh Ling ${ }^{2} \&$ Azlan Abdul Rahman ${ }^{3}$ \\ ${ }^{1}$ Universiti Putra Malaysia Bintulu Sarawak Campus, ${ }^{2}$ Xiamen University Malaysia, \\ ${ }^{3}$ Universiti Teknologi MARA Kedah \\ Email Correspondence: karmilah.abdullah@upm.edu.my
}

\begin{abstract}
The public learns about conservation through the media. While mainstream media have been found to not focus on reporting on this issue in the Malaysia, little research has examined how media frame conservation issues. This paper aims to examine the heritage conservation issues in the mainstream newspapers in Malaysia. The management of conservation issue often arise where groups have different goals or priorities leading to the conflicting emphasis on this issue. As such, media can play an important dual role in to offer insights and the various stakeholders perceive shape on the particular issues. Examining media frames of these newspapers in the construction of heritage conservation would identify the perspective of the issue being discussed in the media. This study used framing as the theoretical framework and content analysis as the research method to examine the role of newspaper in constructing heritage conservation identity and the effect in pushing the conservation movement. Data were collected from 2008 to 2018 and it was found that over the 10 years' period, only 116 articles are covered on this issue. This illustrates that, the media have not put much attention on this issue. The unbalanced media coverage rate over the years sampled suggest opportunities for increased media engagement on this particular issue to further encourage participation of the public towards the conservation and preservation, thus, creating and engaging citizen on these issues are important to best meet the efforts.
\end{abstract}

Keywords: Heritage Conservation, Framing Theory, Content Analysis, Conservation News Reporting

\section{Introduction}

The concept of heritage is moving towards a value-based approach since the early 1980s, which addresses the city as a "living heritage" and thus integrates the associative values and multiple perspectives from different stakeholders (Poulios, 2014; Ginzarly et al., 2019). The various stakeholders approached the appreciation towards the heritage differently which based on their own interests and value systems. Heritage is able to attract much wider attention from specialists in Anthropology, Archaeology, Geography, History and Sociology because of its dynamic links to memory, culture and society (Nakano, 2018). Conservation and preservation of the heritage building are able to bridge the past to the present people. Despite the growing attention to conservation and the protection of these heritage sites, the 
current media discourse on this issue remains rather simplistic, focusing mainly on reporting facts of the information on the heritage sites merely as a tourism destination. Thus, media coverage on the conservation issues are vital in creating more awareness and education to the public.

Message that is framed by the media is one of the communication strategies designed to influent perceptions, attitudes, and judgements (Pelletier \& Sharp, 2008). Past literature on framing has suggested that people think in terms of unconscious structures called frames in order to make sense of the world (Goffman, 1974; Lakoff, 2010). In the same vein, Lakoff (2010) stated that all of our knowledge makes use of frames, and that every word is defined through the frame, which it activates; accordingly, all thinking and talking involved the "framing". Past study based on empirical data is still inadequate or inconsistent regarding the role of message framing as a strategy in the applied context of promoting biodiversity conservation and other environmentally sustainable behaviors (Chang \& Wu, 2015; Cheng, Woon, \& Lynes, 2011; Jacobson et al., 2015). The analysis of news media can produce important insight into emerging 'wicked' problems such as conservation, as the news media can act as both a useful outlet for actors to convey their perspectives on an issue, and a powerful actor that can influence public opinions and actions (Schweinsberg et al., 2017).

To date, much of the research have been focusing on the role of the media in communicating science to the public (e.g., Crouzat et al., 2018; Tinch et al., 2018). However, less attention is paid to the research that emphasizes on the role of media in communicating the awareness of conservation particularly on heritage sites. A significant gap remains, still between public concern for the environment and their actions (Jacobson et al., 2015). Limited research on environmental topics has found that results of framing studies have been inconsistent or may vary with the reference point or timeframe used. Thus, it is crucial to ensure that the awareness and knowledge towards conservation are being clearly communicated towards the public. In supporting this effort, mass media are increasingly recognised as a pivotal part of the conservation efforts. The media collect, frame, and distribute information and can be an important notion in portraying and shaping conservation awareness towards the public (Gore et al., 2005; Rust, 2015; Showkat, 2016). In the broader term, the success of conservation may be championed by educating the community about conservation issues and promoting sustainable behaviours among them (Gusset \& Dick 2010) and by contributing to conservation objectives outlined in global strategic plans (Moss et al. 2015) via the mass media. Thus, examining media framing in terms of heritage conservation is quintessential in deeper understanding of this issue.

\section{Literature Review \\ Heritage Conservation}

Heritage conservation is essential as it provides a sense of identity and continuity in a fastchanging world for future generations. Conservation practice evolves over the decades since its formal introduction and has moved from its initial, almost exclusive, focus on old buildings to a broader view (Armitage \& Irons, 2013). This has led the publics, professional and scholars become more concern and aware to the cultural heritage. The concern on heritage is not only limited to the monuments and buildings but also the conservation process and final appearance of the heritage buildings added to and taking assorted tangible and intangible forms. It is known that heritage is something inherited down from one generation to another (Harrison, 2010; Prentice, 1994; Timothy, 2018). Through the conservation of the heritage monuments and buildings that are passed on, the heritage is then inherited to the future 
generations in which what is currently identified as part of cultural significance today. The heritage would be difficult to be passed on if the best practice approach to the maintenance management of heritage buildings is not fully adopted. Conservation is understood to encompass any action designed to maintain the significance of a heritage object or place and is a process that starts at the moment a place is recognised as having cultural values and singled out for protection. In the past and the present, conservation is an attempt to control and direct change (de la Torre, 2013). This implies that, conservation consisted of attempts to prevent decay of the physical elements that are believed to embody these values.

Conserved heritage can benefit social and cultural functions by inculcating national and civic pride and connect people to the past (Armitage \& Irons, 2013; Henderson, 2012). In line with this, according to Armitage and Irons (2013) conservation practice around has been increasing and developing over the past decades. It started since its formal introduction and has moved from its initial stage which focuses solely on old buildings to a broader view which is more than just historically significant.

As heritage has come to encompass varied places, the protection of the significance of the different type of heritage presents its own conservation challenges. However, the appreciation of heritage according to Geffe (2004) is considered low. Parallel to this, Azahari and Mohamad (2012) stated that, the public awareness of preserving the heritage is largely based on the changes of social and economic environment. This illustrates that, the appreciation of heritage or the conservation is merely for its economic value rather than the intangible value of the place. It could be said that heritage is widely regarded as an important form of economic and social cultural capital to be used in pursuit of assorted beneficial goals within a country. Two main issues concerning the public on preserving the built environment heritage are the creation of new jobs and the need to maintain the novelty of products. In highlighting this, Woon, Chatterjee and Cordery (2019) stated that listing the heritage resources is vital for its protection, conservation and transmission of the values which focuses on its economic benefits. Hence, it is crucial to raise the awareness among the public to ensure that the heritage is preserved for both the benefits of the economics of the country as well as the values for its future generations. In supporting this, Henderson (2012) explained that conservation implies a degree of intervention and perhaps modification to ensure a building's survival and safeguarding. This denotes that, heritage acts as a significant tool in assisting social and cultural functions by inculcating national and civic pride and feelings of connection between the future generation and their past as well as helping to connect people together. In line with this, according to UNESCO (2017), one of the vital issues in preserving the identity of nations is by protecting civilizations, heritages, and the world's diversity of cultures. As to add on, preserving and maintaining heritage will strengthen the city's identity for its inhabitants and increase social solidarity (Zandieh \& Seifpour, 2019). Thus, preserving the heritage of the place will increase the identity of the place and people around it as well as generating economic income.

\section{Heritage Conservation in Malaysia}

In Malaysia, the responsibility for preservation work is placed under the National Heritage Department (JWN). Malaysia is rich with its history and its evolving cultures which are demonstrated through its heritage buildings. The heritage classification is not only something that is passed down from generation to generation such as customs, culture, areas, buildings, archival materials, and printed material but, they are more than that (National Heritage Department, 2012). Malaysia's unique building and architecture are further enriched with 
the cultural aspect of the country from the past history (Sodangi et al., 2013). The buildings reflect the cultural identity of the country and its people's identity. Additionally, to certain extend, it may provide the aesthetic quality of a heritage place or from a sense of identity, belonging or connection that the heritage place promotes in the community (Armitage \& Irons, 2013).

According to Idrus, Khamidi, and Sodangi, (2010), Malaysia encompasses a diverse rich and distinctive multicultural architectural heritage with strong Islamic, Chinese, and Western influences which are all portrayed in the heritage buildings. The long history trail of the colonisation by others such as Portuguese, Dutch, and British has left visible evident in which it is presented until today as presence of the unique colonial architectural and styles. Additionally, cities such as George Town, Ipoh, Kuala Lumpur, Kuching, Malacca, and Taiping have many historical buildings that were built during the colonial era (1511 -1957) with the reflection of different architectural styles that were influenced by different colonisation. Heritage has become one of the Malaysia's key attractions to outsiders, especially after the twin declaration of Malacca and Penang as World Heritage Sites (WHS) by United Nations Educational, Scientific and Cultural Organisation (UNESCO) in 2008 (The Star, 2008).

Conservation activities require immense efforts from the country despite the location of the heritage sites. This is especially when a place receives official recognition as a heritage 'site', its relationship with the landscape in which it exists and with the people who use it immediately changes (Harrison, 2010) and more so if it has become a necessity for socioeconomic development and ultimately sustainable development for human survival (Chan et al., 2010). This is not an exceptional to Malaysia and thus to comprehend the conservation efforts in Malaysia, the public awareness and education should be increased among the public. To date, the public awareness on the significant of heritage conservation for its economic perspective consideration has heightened in Malaysia (Hashim et al., 2013) as the growth of tourism has boosted in the emergence of heritage tourism within Malaysia.

\section{Theoretical Framework}

This study relies on framing theory as the theoretical framework. In the field of media and communication studies, Tuchman (1978) and Gitlin (1980) are the two earliest scholars to apply framing to communication research. They suggested that news is a social construction, and the media play an important effect on what is perceived by the public to be reality. They also asserted that media representation often coincides with the definition that is provided by the holder of power, or the elites in the society. In that manner, the media allow this dominant group to be opinion leaders to define events or issues, and subsequently shaping others' values, attitudes, and opinions. The concept of framing is often termed as the process of framing involves selection and salience. This implies that some aspect, event, or issues that are perceived important and significant to the public being selected, making it salient in a communication context. Therefore, the issue or event can promote and unravel, for instance a prominent problem can be defined and/or treatment recommendation (Entman, 1993). However, the concept of framing is not entirely applicable in the media and communication studies. In fact, it is originated from the fields of cognitive psychology and anthropology. It was then later adopted by other disciplines, often with a shift in meaning, including sociology, economics, linguistics, social movement research, policy research, communications science, political communications, public relation research and health communication (Bryant \& Miron, 2004). 
Framing would be able to focus on how the media grab the attention of the public towards specific topics, setting the agenda, and then it takes a step further to create a frame, through which the audience will comprehend such information. Creating frames for stories is commonly a mindful choice by sources, reporters, journalists and/or editors (Ardèvol-Abreu, 2015). The issue or topic that is emphasised will further to be framed in a specific theme in addition to making it more salient to the public. The particular issue will then be highlighted in the media using selected keywords, sentences, images, sources of information, etc, illustrating the issue with more salient towards the public. According to Entman (1993) the text that is framed, however, will induce the receiver to ponder on the issue over and give an impact to the culture ultimately. The key to the process of framing is the role of mass media. The method used to frame with issue by the media could initiate or prompt different perceptions and thinking among the individuals. This will then lead to the different results of respond by the people when they obtained the information framed, either positively or negatively (Ferguson \& Gallagher, 2007). Therefore, mass media are significant in transmitting information and they have the capabilities to shape people's opinion towards certain issues. The main fundamental and important of framing is selection and highlighting. The media coverage has the capabilities to impact on how the public and policy maker to be more aware of and think about an issue that is important (Soroka, 2002). Therefore, discussing about competing and multiple frames, Scheufele and Tewksbury (2007) asserted that the reader will involve in a systematic break down of the information that they obtained by comparing the relative strength of different frames in competitive situations, hence leading them to come out with different conclusion on the idea being promoted by the frames. On the other side of the coin, it is suggested by Chong and Drukman (2007) individual who are being exposed repeatedly by the frames would have greater impact on those who are less knowledgeable on the subject matter and on those who are more likely to be influenced by the peripheral cues. Additionally, other contributing factors that play an essential role in frames are frequency, accessibility, and relevance. Frequency is referred as the number of times the media repeats the particular frame being presented. The more the story or frame is being repeated, the greater the force, impact or emphasis is placed on the particular frame. Accessibility and repetition are placed together as a pair due to its accessibility in improving repetition. While relevance is defined as the core of the subject matter based on peripheral cues, this refers to the stimuli that will influence individuals on a particular subject matter. This implies that the effects of framing are unpredictable and may have impact towards the public based of issues per say. Hence, coverage on an issue or event in terms of heritage conservation based on certain themes and attributes would be able to provide deeper understanding and impact to public opinion in perceiving the issue.

Additionally, frame valence, such as how the media report on an issue, whether it is positively or negatively expressed, has been suggested to influence public support for specific policies (de Vreese \& Boomgaarden, 2003). This can therefore be seen, if the media coverage portrays negative events, such as attacks by animals, can amplify perceived risk, and reduce support for conservation interventions (Jacobson et al., 2012). The media is also able to emphasis on significant "messengers" in a debate (e.g. scientists, politicians, celebrities) to deliver different perspectives (Muter et al., 2013); this choice of messenger is able to influence how the readers perceive the particular issue (Jacobson et al., 2012). The role of media is thus not as straightforward as it can both reflect measures of public opinion (e.g., media outlets might only publish something that they believe is of interest to their target readership) as well as 
influence public perceptions, but ultimately acting as an additional sector in the conservation process with its own goals (Papworth et al., 2015).

\section{Research Questions}

Based on the theoretical framework, the researchers formulated the following research questions related to framing of conservation news stories in the media.

RO1: What are the frames employed by The Star and New Straits Times to portray the issue of heritage conservation in Malaysia?

RO 2: What are the themes discussed with regards to the issue of heritage conservation?

\section{Methodology}

This study employed the method of content analysis in scrutinising the media frames portrayed in the heritage conservation coverage. Five daily newspapers were selected based on their circulation and geographical coverage. Berita Harian, Utusan Malaysia and Kosmo are the most influential Malay dailies meanwhile New Straits Times and The Star represent the English sector. Research framework plays an important role in providing a structure and in detailing the linkages among all variables in this study. The framework demonstrated in Figure 1 depicts the work carried out in content analysing the news reports on the issue of the study.

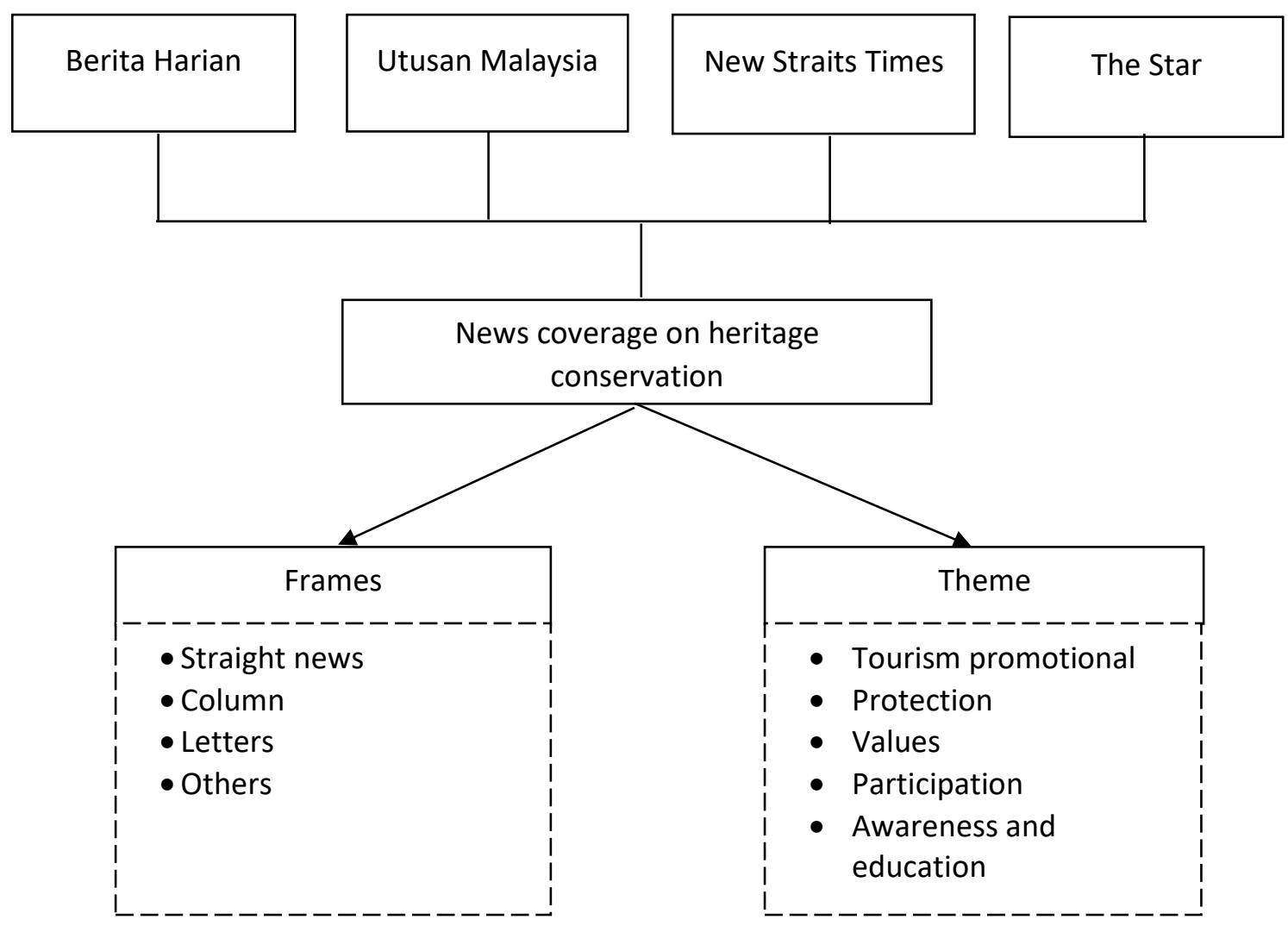

Figure 1: Research Framework

This study attempts to analyse how the newspaper reports conservation-related news articles in the selected time frame. Thus, the conservation-related news articles were examined from the June 1st, 2008, to July 31th, 2018. The reason of selecting those periods is due to the declaration of the UNESCO WHS.

All the news articles that appeared in the daily with the keywords "conservation of the heritage sites in Malaysia" were scrutinised, therefore, the units of analysis were the news 
articles. There were 116 articles identified during the periods. The first research question asked, "What are the frames employed by the mainstream newspaper to portray the issue of heritage conservation in Malaysia?" This study employed the inductive or emergent coding approach for analysing frames (Elo \& Kyngäs, 2008). The coding categories were outlined after a preliminary examination of the data. As a result, four categories of frames were identified in this study:

1. Straight news - basic straightforward news stories, usually providing facts and information.

2. Column - a recurring space in a newspaper where a writer regularly expresses their own research/views/opinions; and including features.

3. Letters - letters by individuals and general public giving their lay or expert views on an issue/topic.

4. Others - which are not categorised under any of the above frames.

Based on the second research questions, the themes that have been discussed with regard to the issue of heritage conservation resulting in the following initial codes of themes expected in the news articles. These themes were collected based on the previous research done by Goh (2015) and then modified to the need of this study. Therefore, the five themes used in this study are:

1. Tourism promotional - tourism sites promotion

2. Protection - preservation activities and conservation activities

3. Values - heritage values and community values

4. Participation - stakeholder participation and community involvement

5. Awareness and education - Awareness and educational program related to heritage conservation

\section{Data Analysis and Inter-Coder Reliability}

The 116 news articles collected from the local mainstream newspapers were analysed using descriptive statistics such as frequencies and percentage, as well as qualitative interpretation. In categorising and measuring the content element, there is a risk of subjectivity in interpreting the context units therefore a second coder was appointed to code the data. The defect of wrong decision would definitely influence the research outcome. As to ensure high reliability in this study, various rounds inter-coder reliability tests were conducted. The coders' decisions in categorising the units during the pilot study were checked against each other's decisions and Holsti's (1969) percent agreement index was applied in this statistical procedure. Reconciliations were conducted among the three coders for the low agreement indexes found. It was until all indexes achieved the required value of .7, or the acceptable level by convention, the coders were then allowed to proceed with data analysis. Randomised dates from all the different news coverage were selected and assigned to these three coders and this procedure was to ensure equal treatment.

\section{Results and Discussion}

\section{Extent of News Coverage}

Table 1 shows a total of 116 analysed news articles gathered from 2008 until 2018 which consisting of 40 articles from The Star, 59 articles from New Straits Times, 12 articles from Utusan Malaysia, three articles from KOSMO and two articles from Berita Harian. 
Table 1: Distribution of news articles

$\begin{array}{lllllll}\text { Year } & \text { The Star } & \text { NSTP } & \begin{array}{l}\text { Utusan } \\ \text { Malaysia }\end{array} & \text { KOSMO } & \begin{array}{l}\text { Berita } \\ \text { Harian }\end{array} & \text { Frequency } \\ 2008 & 4 & 7 & 5 & 1 & 0 & 17 \\ 2009 & 3 & 13 & 2 & 1 & 0 & 19 \\ 2010 & 0 & 9 & 1 & 1 & 0 & 11 \\ 2011 & 10 & 8 & 2 & 0 & 0 & 20 \\ 2012 & 0 & 7 & 0 & 0 & 0 & 7 \\ 2013 & 0 & 3 & 1 & 0 & 0 & 4 \\ 2014 & 10 & 1 & 1 & 0 & 0 & 12 \\ 2015 & 0 & 1 & 0 & 0 & 0 & 1 \\ 2016 & 10 & 7 & 0 & 0 & 2 & 17 \\ 2017 & 0 & 2 & 0 & 0 & 0 & 2 \\ 2018 & 3 & 1 & 0 & 0 & 0 & 4 \\ \text { Total no. of } & \mathbf{4 0} & \mathbf{5 9} & \mathbf{1 2} & \mathbf{3} & \mathbf{2} & \\ \text { articles } & & & & & & \end{array}$

The distributions of news coverage of conservation in the selected newspapers are inconsistent during the study time frame as illustrated in Figure 1. The New Straits Times was the only news agency that actively reporting the heritage issues every year during the study period. However, in 2008 and 2009, there were 17 and 19 articles were published by all selected newspapers which explains the active reporting was linked to the announcement of UNESCO World Heritage Sites in 2008. As stated in Table 1, the frequency of published articles is highest in 2011 with 20 articles and followed by 2009 (19 articles), 2008 (17 articles) and 2016 (17 articles) which in total of 73 published articles.

In comparison, English-language newspapers published more articles with the percentage of 85.3\% (99 articles) as compared to Bahasa Malaysia- language newspapers which published only 17 articles in total. The difference in the number of articles published by the five newspapers revealed that they carried unequal weight of attention to the heritage conservation issue. The findings demonstrated that NSTP is the most concerned with the issue, followed by The Star, Utusan Malaysia, KOSMO and Berita Harian. 


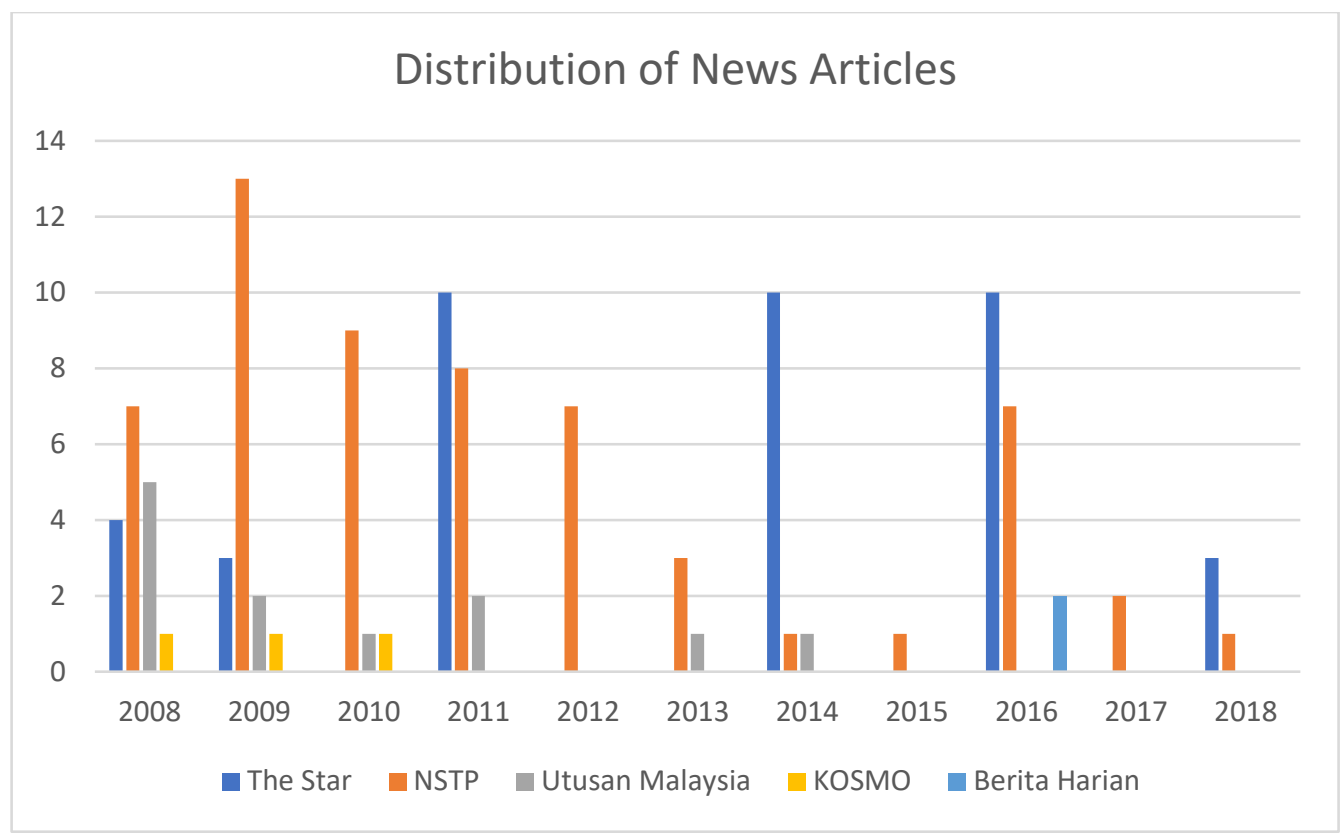

Figure 2: Distribution of news articles

\section{Location}

Figure 2 shows the news coverage based on location. Based on the findings, it could be identified that majority of the selected newspapers have covered all the UNESCO- heritage sites listed in Malaysia especially on historical cities of Georgetown, Penang and Malacca. Only two newspapers namely, The Star and NSTP have covered UNESCO heritage sites of Kinabalu Park Sabah and Gunung Mulu Park, Sarawak. The analysis shows that all newspapers have reported on heritage conservation issues in Georgetown, Penang which scored the highest coverage with 59 published articles. Kuala Lumpur scored the second highest rank with 17 articles, and they are mostly from The Star, NSTP and Utusan Malaysia. The third rank goes to other locations apart from Penang, Kuala Lumpur, Melaka, Perak, Sabah, Sarawak and Pahang with a total of 12 published articles.

\section{Location}

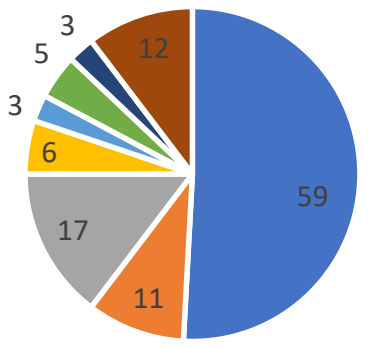

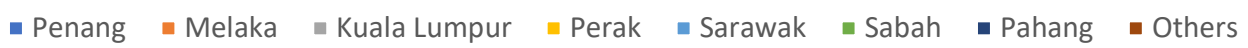

Figure 3: Location of news coverage 


\section{Types of News}

Based on the content analysis, six categories of type of news were identified in this study namely straight news, editorial, column, opinion, letters, and others. However, straight news, column and letters ranked as the top three highest type of news reporting in The Star, NSTP, Utusan Malaysia, KOSMO and Berita Harian. Table 2 shows that the straight news scored $63.7 \%$ (74 articles) which predominates the type of news reporting followed by Column with $27.6 \%$ ( 32 articles) and letters 5\% (6 articles). Table 2 indicates the distribution of articles based on the type.

\begin{tabular}{|c|c|c|c|c|c|c|c|}
\hline $\begin{array}{l}\text { Type of } \\
\text { news }\end{array}$ & Characteristics & $\begin{array}{l}\text { The } \\
\text { Star }\end{array}$ & NSTP & $\begin{array}{l}\text { Utusan } \\
\text { Malaysia }\end{array}$ & KOSMO & $\begin{array}{l}\text { Berita } \\
\text { Harian }\end{array}$ & Total \\
\hline $\begin{array}{l}\text { Straight } \\
\text { news }\end{array}$ & $\begin{array}{l}\text { Basic straightforward } \\
\text { news stories, usually } \\
\text { providing facts and } \\
\text { information. }\end{array}$ & 32 & 31 & 7 & 2 & 2 & 74 \\
\hline Column & $\begin{array}{l}\text { A recurring space in a } \\
\text { newspaper where a } \\
\text { writer regularly } \\
\text { expresses their own } \\
\text { research/views/opinions; } \\
\text { and including features }\end{array}$ & 6 & 21 & 4 & 1 & 0 & 32 \\
\hline Letters & $\begin{array}{l}\text { Letters by individuals } \\
\text { and general public giving } \\
\text { their lay or expert views } \\
\text { on an issue/topic }\end{array}$ & 2 & 3 & 1 & 0 & 0 & 6 \\
\hline
\end{tabular}

\section{News Source}

News sources are important in determining the reporting and it reflects the direction in terms of development and inclination of a newspaper (Yang \& Ishak, 2012). The findings in table 3 have stated that all five newspapers depended heavily on authorities including government officials and ministers as their news source with a total of 75 articles (64.7\%). The academicians are the next predominant source with $20.7 \%$, followed by others $(11.2 \%)$ and general public (6\%).

Fahmy (2005) suggested that the news sources might influence the flow of information and the basic of the stories through the media. This study identified that there is an exceptional consistency across all selected newspapers that referred authorities as the major news source. This shows that these newspapers turned to the official sources which are more credible than non-official sources. Since public official sources tend to speak a universalising and rationalising information, the heavy reliance on public official as the news sources tend to legitimize the state and its policy (Yang \& Ishak, 2011).

From the findings, The Star, NSTP and Utusan Malaysia also used academician and other professional or experts such as architect, business manager and business owner whenever the situations warrant their expertise on the strategies regarding heritage conservation. These three newspapers also included voices of local community in pursuing the bottom line. Table 3 shows the distribution of articles based on news sources. 


\begin{tabular}{llllll} 
& \multicolumn{9}{c}{ Table 3: Sources of news } \\
Sources & The Star & NSTP & Utusan Malaysia & KOSMO & Berita Harian \\
Authorities & 29 & 34 & 8 & 3 & 1 \\
Academician & 2 & 21 & 1 & 0 & 0 \\
General Public & 2 & 3 & 2 & 0 & 0 \\
Others & 7 & 4 & 1 & 0 & 1
\end{tabular}

\section{Themes}

This study employed an inductive or emergent coding theme for analyzing heritage conservation issue. As a result, there were five themes identified in this study, which consist of tourism promotional, protection, values, participation and awareness and education. These themes were generated based on the previous research done by Goh (2015) and modified to the need of this study. Table 4 below describes the different types of themes, its characteristics and distribution of news coverage based on themes.

\begin{tabular}{|c|c|c|c|c|c|c|c|}
\hline \multirow[t]{2}{*}{ Themes } & \multirow[t]{2}{*}{ Characteristics } & \multicolumn{5}{|c|}{ No. of articles } & \multirow{2}{*}{$\begin{array}{l}\text { Frequenc } \\
y\end{array}$} \\
\hline & & $\begin{array}{l}\text { The } \\
\text { Sta } \\
r\end{array}$ & $\begin{array}{l}\text { NST } \\
P\end{array}$ & $\begin{array}{l}\text { Utusan } \\
\text { Malaysi } \\
\text { a }\end{array}$ & $\begin{array}{l}\text { KOSM } \\
\mathrm{O}\end{array}$ & $\begin{array}{l}\text { Berita } \\
\text { Haria } \\
\mathrm{n}\end{array}$ & \\
\hline $\begin{array}{l}\text { Tourism } \\
\text { promotional }\end{array}$ & $\begin{array}{l}\text { Tourism sites } \\
\text { promotion }\end{array}$ & 5 & 13 & 5 & 1 & 0 & 24 \\
\hline Protection & $\begin{array}{l}\text { - Preservation } \\
\text { activities } \\
\text { - Conservatio } \\
\text { n activities }\end{array}$ & 13 & 19 & 4 & 2 & 2 & 40 \\
\hline Values & $\begin{array}{l}-\quad \text { Heritage } \\
\text { values } \\
\text { - } \quad \text { Community } \\
\text { values }\end{array}$ & 9 & 13 & 3 & 0 & 0 & 25 \\
\hline $\begin{array}{l}\text { Participatio } \\
\text { n }\end{array}$ & $\begin{array}{l}\text { - Stakeholder } \\
\text { participation } \\
\text { - Community } \\
\text { Involvement }\end{array}$ & 5 & 13 & 0 & 0 & 0 & 18 \\
\hline $\begin{array}{l}\text { Awareness } \\
\text { \& education }\end{array}$ & $\begin{array}{l}\text { Awareness and } \\
\text { educational } \\
\text { program related to } \\
\text { heritage } \\
\text { conservation }\end{array}$ & 8 & 1 & 0 & 0 & 0 & 9 \\
\hline
\end{tabular}

Based on Table 4, protection theme scored the highest priority in all selected newspapers with a total of 40 articles (34.5\%). Under this theme, news report portrayed the strategies, initiatives and solutions that were undertaken to protect the heritage buildings and sites. This 
explains the significance of preserving and conserving the heritage for the future. Values theme ranked as the second highest with 25 reported articles, followed by tourism promotional theme (24 articles), participation theme (18 articles) and awareness and education theme with 9 articles. Table 4 also reports that The Star, NSTP, KOSMO and Berita Harian paid more attention to protection theme with 32.5\% (13 articles), 32.2\% (19 articles), $66.6 \%$ ( 3 articles) and 2 articles respectively of the reported news coverage on the preservation and conservation activities. Meanwhile, Utusan Malaysia covered $41.7 \%$ of the news reporting on tourism sites promotional and only 8 articles published by The Star and NSTP can be categorised under the awareness and education theme.

\section{The Star}

Table 5 shows the examples of the headlines reported in The Star during the study period. In terms of themes, protection theme is given the highest priority in The Star news reporting followed by values and awareness and education theme.

Table 5: Examples of headlines under the examined themes

\begin{tabular}{|c|c|c|}
\hline Themes & Headlines & $\begin{array}{l}\text { Number of } \\
\text { articles }\end{array}$ \\
\hline \multirow[t]{3}{*}{$\begin{array}{l}\text { Tourism } \\
\text { promotional }\end{array}$} & $\begin{array}{l}\text { - } \quad \text { An attraction par excellence (19 December 2016) } \\
\text { - } \quad \text { Fascinating historical at Masjid Jamek (28 October } \\
\text { 2014) }\end{array}$ & 5 \\
\hline & $\begin{array}{l}\text { Komtar reborn with new wonders (19 December 2016) } \\
\text { 2008) }\end{array}$ & \\
\hline & $\begin{array}{l}\text { - Shophouses being restored as co-living and } \\
\text { commercial spaces ( } 22 \text { May 2018) }\end{array}$ & \\
\hline \multirow[t]{9}{*}{ Protection } & $\begin{array}{l}\text { - Apply KL Chinatown solution elsewhere (25 August } \\
\text { 2011) }\end{array}$ & 13 \\
\hline & $\begin{array}{l}\text { - Badan Warisan facing uphill task to save old buildings } \\
\text { (6 September 2011) }\end{array}$ & \\
\hline & $\begin{array}{l}\text { Badan Warisan: Proposal is a big step backwards (20 } \\
\text { October 2014) }\end{array}$ & \\
\hline & $\begin{array}{l}\text { Do restoration activities in stages, state urged (26 } \\
\text { September 2008) }\end{array}$ & \\
\hline & $\begin{array}{l}\text { - Govt to apply for joint world heritage status (1 July } \\
\text { 2011) }\end{array}$ & \\
\hline & $\begin{array}{l}\text { - Indonesia pledges to protect ancient cave paintings (9 } \\
\text { October 2014) }\end{array}$ & \\
\hline & $\begin{array}{l}\text { Many Penang guesthouses to close for good (1 } \\
\text { November 2016) }\end{array}$ & \\
\hline & $\begin{array}{l}\text { - On urban conservation (4 February 2009) } \\
\text { - Penang submitted proposal on management of } \\
\text { RM25m allocation for heritage ( } 20 \text { April 2009) }\end{array}$ & \\
\hline & $\begin{array}{l}\text { - Preserving old buildings on canvas (20 September } \\
\text { 2011) }\end{array}$ & \\
\hline
\end{tabular}




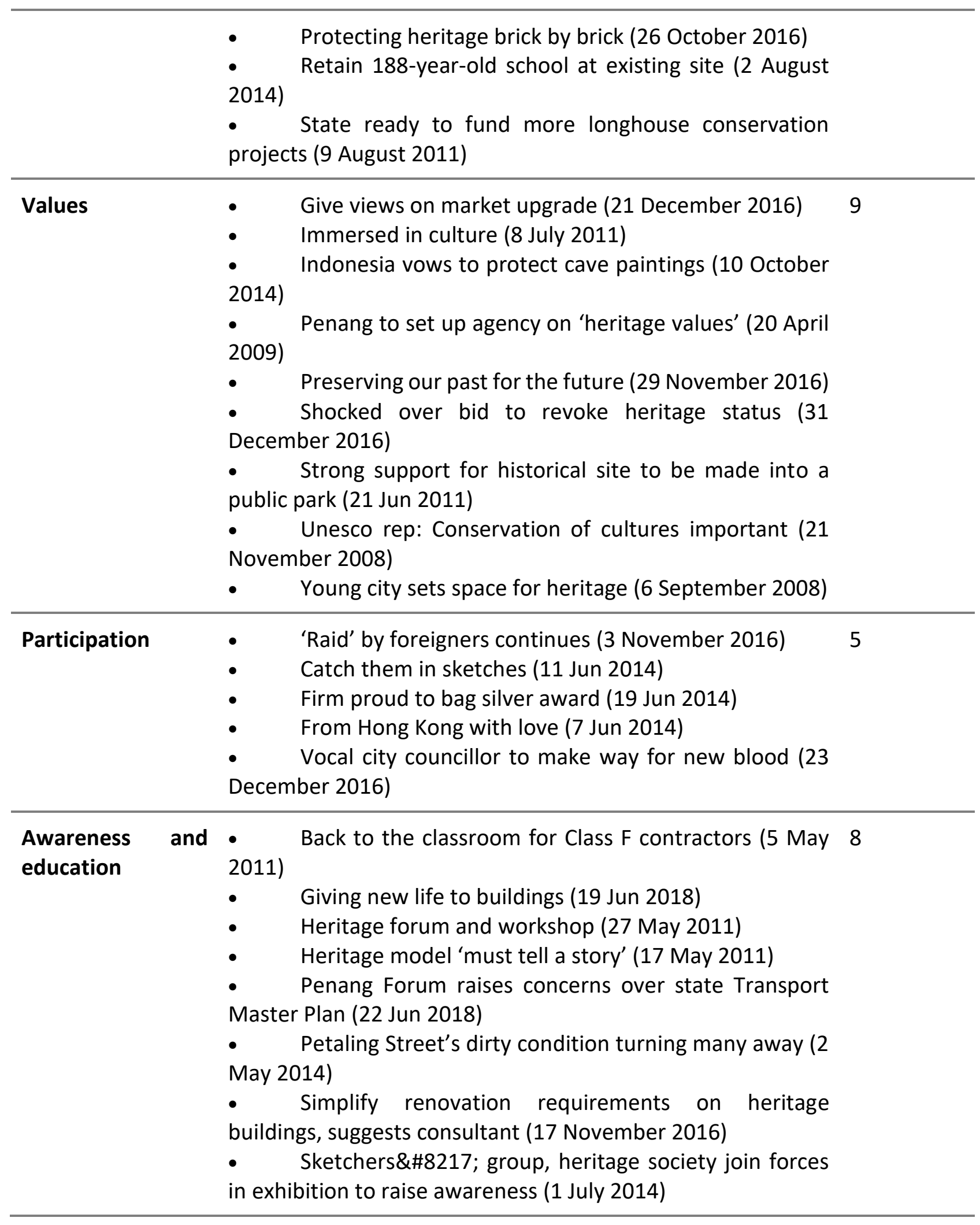

Below are the examples of excerpt taken from The Star:

"But the important thing is to prioritise what needs to be done. Also, if you are not aware of what is valuable, you won't know if the building's original timber is replaced with a cheap substitute. Make sure that your contractor is professional, experienced and ethical" (The Star- September 26, 2008: Affordable Conservation) 
"Malaysian Institute of Architects (PAM) heritage conservation committee member and architect Mariana Isa said the staircase was part of the original mosque design from more than a hundred years ago".

(The Star- January 8, 2018: Fascinating historical find at Masjid Jamek)

\section{The New Straits Times}

Among the five newspapers, The New Straits Time ranked the highest distribution of heritage conservation news during the study period. Based on the analysis, NSTP also gave most attention to the issue of preserving and conserving the heritage sites in Malaysia. Majority of the articles reported the support from various parties including the government in restoration activities on tourist hotspots and impressive heritage buildings. $32.2 \%$ or 19 articles of its published articles fall under the protection theme, $66.1 \%$ of the articles were classified under tourism promotional, values, and participation theme which recorded 13 articles respectively and only one article was classified under awareness and education theme. Table 6 shows the example of headline and excerpt that are categorised under these five themes.

Table 6: Theme, headline, and excerpt

\begin{tabular}{|c|c|c|}
\hline Theme & Headline & Excerpt \\
\hline $\begin{array}{l}\text { Tourism } \\
\text { promotional theme }\end{array}$ & Restored heritage & $\begin{array}{l}\text { "Suffolk house is available for parties and } \\
\text { formal functions. Its beautiful historical setting } \\
\text { makes it great for photography. So, next time } \\
\text { you are making way to Penang, drop by at } \\
\text { Suffolk House for a wonderful heritage } \\
\text { experience" }\end{array}$ \\
\hline Protection theme & $\begin{array}{l}\text { Heritage preservation } \\
\text { efforts growing }\end{array}$ & $\begin{array}{l}\text { "Malaysians are soaring up the work of } \\
\text { conserving and preserving heritage sites on our } \\
\text { own volition" }\end{array}$ \\
\hline Values theme & $\begin{array}{l}\text { Stadium, Suffolk } \\
\text { house get award }\end{array}$ & $\begin{array}{l}\text { "Stadium Merdeka and Suffolk House received } \\
\text { accolades award in this year's UNESCO Asia } \\
\text { Pacific Heritage Awards for culture and } \\
\text { heritage conservation" }\end{array}$ \\
\hline $\begin{array}{l}\text { Participation } \\
\text { theme }\end{array}$ & $\begin{array}{l}\text { Three days to mark } \\
\text { heritage listing joy }\end{array}$ & $\begin{array}{l}\text { "Chief Minister, Lim Guan Eng led a group of } \\
\text { more than } 100 \text { people including State } \\
\text { Executive Councillors, Assemblymen, State } \\
\text { Government Officials, and representative of } \\
\text { NGOs on the three-hour walk" }\end{array}$ \\
\hline $\begin{array}{l}\text { Awareness and } \\
\text { education theme }\end{array}$ & $\begin{array}{l}\text { Workshop on } \\
\text { preserving heritage } \\
\text { buildings }\end{array}$ & $\begin{array}{l}\text { "The forum and the workshop aim to raise the } \\
\text { level of interest and awareness in conservation } \\
\text { and at the same time develop realistic } \\
\text { frameworks and the way forward for the } \\
\text { George Town World Heritage Site" }\end{array}$ \\
\hline
\end{tabular}

\section{Utusan Malaysia}

Utusan Malaysia devoted the most coverage on promoting heritage tourism sites (tourism promotional theme). Utusan Malaysia reported the uniqueness of heritage sites can be one of the tourism products. For example, the headline of news 'Ulu Salan Berubah Wajah'. In this news article, Utusan Malaysia reported that, the physical environment can be one of the main 
sources of tourism and travelers have used to visit the heritage site and its natural environment by the motive of getting experience. Below is the example of excerpt taken from this article:

"Berada di Ulu Salan, Jerantut, pasti ramai yang terpegun dengan keindahan alam sekitarnya memandangkan flora dan fauna di sini sentiasa terpelihara"

(Utusan Malaysia- January 1, 2011: Ulu Salan Berubah Wajah)

Under this theme, there are also some news stories on promotional heritage sites such as 'Rumah the Bunga Imbas Sejarah Silam', 'Melaka dan Georgetown Bandar Sejarah Selat Melaka', 'Lembah Lenggong Tapak Warisan' and 'Kegemilangan Kota Johor Lama'.

\section{KOSMO}

There were only three articles published during the study period. Two articles from KOSMO were categorized under protection theme. The headlines for both articles are 'Nostalgia Kelahiran Najib Tun Razak' and 'Lebih Banyak Warisan Negara Dikenal pasti'. Below are the examples of excerpt taken from both articles

"Nilai sejarah di rumah itu snagat penting untuk tatapan generasi akan dating kerana ia menyaksikan bekas Perdana Menteri Kedua tinggal di situ dan kelahiran Perdana Menteri Keenam di rumah yang sama"

(KOSMO- April 9, 2010: Nostalgia Kelahiran Najib Tun Razak)

"Jabatan Warisan Negara akan berusaha meningkatkan lagi kepakaran dalam bidang konservasi terutama dalam kerja-kerja membaik pulih bangunan warisan"

(KOSMO- November 9, 2009: Lebih Banyak Warisan Negara Dikenal pasti)

Meanwhile, KOSMO also reported an article under tourism promotional theme entitled 'Melaka, Georgetown Warisan Dunia'. This news article explained the government is committed to increase financial allocation in order to preserve Melaka and Georgetown to remain as the world heritage sites.

"Peruntukan tersebut bertujuan untuk menjaga dan memulihara mengikut piawaian antarabangsa dalam pelaksanaan kerja-kerja konservasi"

(KOSMO- Julai 9, 2008: Melaka, Georgetown Warisan Dunia)

\section{Berita Harian}

Berita Harian published only two articles that are related to heritage conservation issue during 2008 until 2018. Both articles highlighted the importance of protecting heritage sites in order to provide a sense of identity and continuity for future generations. The articles entitled 'Pemilik diberi Insentif Pulihara, Selenggara Premis' and 'Pusat Kusta Bakal Jadi Tapak Warisan'. Excerpts taken from both articles are as follows:

"Pihaknya memelihara dan memulihara persekitaran bangunan warisan yang dimiliki kerajaan negeri di bawah Pembangunan Pulau Pinang (PDC). Usaha ini penting untuk mengekalkan warisan kepada generasi muda"

(Berita Harian- August 26, 2016: Pemilik diberi Insentif Pulihara, Selenggara Premis) 
"Jabatan Warisan Negara kini menjalankan proses mengenal pasti bnaan sekitar Pusat Kawalan Kusta Negara untuk diwartakan sebagai tapak warisan bagi membolehkan ia dilindungi dan dipelihara keasliannya"

(Berita Harian- January 16, 2016: Pusat Kusta Bakal Jadi Tapak Warisan)

\section{Conclusion}

Media is a powerful tool in educating public on certain issue. Furthermore, framing theory and research posits that even a small change in the way a single story is written can have effects on readers. From the evidence presented here, it is doubtful those effects are as immediate when it comes to conservation issue as findings show that, over a 10-year period, only 116 articles covered this issue. This study summarises that Malaysian media have not given much attention on the said issue, even though heritage conservation is such a significant subject in Malaysia. This study also found that The New Straits Times gave greater emphasis and attention to heritage conservation coverage compared to The Star, Utusan Malaysia, KOSMO and Berita Harian. This is illustrated by the number of news articles published by the five newspapers over the period of study of 10 years. This concludes that all the five newspapers have a lot of similarities in their reporting on this issue despite having their own principles and ideologies and showed no clear differences in their reporting. This similarity is presented through themes that emerged in this study which are tourism promotional, protection, values, participation, awareness, and education. The type of news reporting of all five newspapers are still predominantly presented as straight news and still relying on the authorities as their main source of information for heritage conservation issues. Based on the news coverage distribution, this study found that English-language newspapers are more interested in this issue as compared to Bahasa Malaysia-language newspapers. Less coverage of this issue might affect the level of awareness among society especially the youth regarding the importance of protecting heritage areas. If there is not much effort in protecting this heritage sites, we would be losing our precious treasures. It is often argued that local communities should be involved in the management of a World Heritage site (Wall \& Black, 2004; Jones \& Shaw, 2012). Therefore, media play an important role in educating and also providing knowledge on the heritage in emphasising the importance of heritage conservation to the public. Through media representations, readers establish a way of making sense about themselves and the world (Yang, 2019). Thus, the media should play their role to raise awareness among Malaysian to work together in conserving the heritage sites for our future generations.

\section{Limitation of Study}

As with any research, this study faced some issues that limited the findings, but could be further explored in the future. While the study took place in its time frame, volume, and thematic coverage, it did not provide a complete, historically representative picture of the issue. Perhaps future research could study the perspective of other newspapers on heritage conservation and the roles of stakeholders in furthering heritage conservation efforts and also policies in governing the conservation of the national heritage, e.g. the government, NGOs, universities and etc. 


\section{References}

Ardèvol-Abreu, A. (2015). Framing theory in communication research in Spain. Origins, development and current situation. Revista Latina de Comunicación Social, 70, 423-450.

Armitage, L. \& Irons, J. (2013). The values of built heritage. Property Management, 31(3), 246259.

Bryant, J., \& Miron, D. (2004). Theory and research in mass communication. Journal of Communication, 54(4), 662-704.

Chan, K. L.G., Hashim, H. S., \& Aziz, S. (2011). Introducing network planning: An Example from Langkawi. Journal of the Malaysia Institute of Planning, 9, 159-184.

Chan, K. L. G., Aziz, S., Hashim, H. S., \& Aziz, R. A. (2010). Sistem jaringan governans untuk Langkawi Geopark: Pengkisahan konseptual. Akademika, 80, 69-84.

Chan, K. L. G. (2014). Jaringan hubungan sosial pemangkin pemuliharaan seiring pembangunan: Kajian kes Langkawi Geopark. In Aziz, R. A., \& Hashim, H. S. (Eds.). Langkawi Geopark mengimbangi pembangunan dan pemuliharaan warisan. Kuala Lumpur: Dewan Bahasa dan Pustaka.

Chang, M. C., \& Wu, C. C. (2015). The effect of message framing on pro-environmental behavior intentions: An information processing view. British Food Journal, 117(1), 339357.

Cheng, T., Woon, D. K., \& Lynes, J. K. (2011). The use of message framing in the promotion of environmentally sustainable behaviors. Social Marketing Quarterly, 17(2), 48-62.

Chong, D., \& Druckman, J. N. (2007). A theory of framing and opinion formation in competitive elite environment. Journal of Communication, 57(1), 99-118.

Crouzat, E., Arpin, I., Brunet, L., Colloff, M.J., Turkelboom, F., \& Lavorel, S. (2018). Researchers must be aware of their roles at the interface of ecosystem services science and policy. Ambio, 47(1), 97-105.

de la Torre, M. (2013). Values and heritage conservation. Heritage and Society, 6, 155-166.

de Vreese, C., \& Boomgaarden, H. (2003). Valenced news frames and public support for the EU. Communications, 28, 361-381.

Elo, S., \& Kyngäs, H. (2008). The qualitative content analysis process. Journal of Advanced Nursing, 62, 107-115.

Entman, R. M. (1993). Framing: Toward clarification of a fractured paradigm. Journal of Communication, 43(4), 51-58.

Fahmy, S. (2005). Emerging alternatives or traditional news gates: Which news sources were used to picture the 9/11 attack and the Afghan war? Gazette, 67(5): 381-398

Ferguson, E., \& Gallagher, L. (2007). Message framing with respect to decisions about vaccination: The roles of frame valence, frame method and perceived risk. British Journal of Psychology, 98(4), 667-680.

Ginzarly, M., Houbart, C., \& Teller, J. (2019). The historic urban landscape approach to urban management: A systematic review. International Journal of Heritage Studies, 1-21.

Gitlin, T. (1980). The whole world's watching. Berkeley and Los Angeles: University of California Press.

Goh, M. H. (2015). UNESCO World Heritage Site of Lenggong Valley, Malaysia: A Review of its Contemporary Heritage Management. Conservation and Management of Archaeological Sites, 17(2), 143-158.

Goffman, E. (1974/1986). Frame analysis: An essay on the organization of experience (new ed.). Lebanon, NH: Northeastern University Press. 
Gore, M. L., Siemer, W. F., Shanahan, J. E., Schuefele, D., \& Decker, D. J. (2005). Effects on risk perception of media coverage of a black bear-related human fatality. Wildlife Society Bulletin, 33, 507-516.

Gusset, M., \& Dick, G. (2010). Building a future for wildlife? Evaluating the contribution of the world zoo and aquarium community to in situ conservation. International Zoo Yearbook, 44,183-191.

Hashim, H. S., Aziz, R. A., Aziz, S., \& Chan, K. L. G. (2010). Governans untuk Geopark: Langkawi sebagai acuan. Akademika, 80, 39-64.

Henderson, J. C. (2012). Conserving heritage in Southeast Asia: Cases from Malaysia, Singapore and the Philippines. Tourism Recreation Research, 37(1), 47-55.

Holsti, O. R. (1969). Content analysis for Social Sciences and Humanities. Massachusetts: Addison-Westley.

Idrus, A., Khamidi, F., \& Sodangi, M. (2010). Maintenance management framework for conservation of heritage buildings in Malaysia. Journal of Modern Applied Science, 4(11), 66-77.

Jacobson, S. K., Langin, C., Carlton, J. S., \& Kaid, L. L. (2012). Content analysis of newspaper coverage of the Florida panther. Conservation Biology, 26, 171-179.

Jacobson, S. K., McDuff, M. D., \& Monroe, M. C. (2015). Conservation education and outreach techniques (2nd ed.). Oxford, UK: Oxford University Press.

Lakoff, G. (2010) Why it matters how we frame the environment. Environmental Communication, 4(1),70-81.

Muter, B. A., Gore, M. L., Gledhill, K. S., Lamont, C., \& Huveneers, C. (2013). Australian and U.S. news media portrayal of sharks and their conservation. Conservation Biology, 27, 187-196.

Nakano, R. (2018) A failure of global documentary heritage? UNESCO's 'memory of the world' and heritage dissonance in East Asia. Contemporary Politics, 24(4), 481-496.

Papworth, S. K., Nghiem, T. P. L., Chimalakonda, D., Posa, M. R. C., Wijedasa, L. S., \& Bickford, D. (2015). Quantifying the role of online news in linking conservation research to Facebook and Twitter. Conservation Biology, 29, 825-833.

Pelletier, L. G., \& Sharp, E. (2008). Persuasive communication and proenvironmental behaviours: How message tailoring and message framing can improve the integration of behaviours through self-determined motivation. Canadian Psychology, 49, 210-217.

Poulios, I. (2014). Past in the present: A living heritage approach - Meteora. Greece. London: Ubiquity Press Ltd.

Rust, N. A. (2015). Media framing of financial mechanisms for resolving human-predator conflict in Namibia. Human Dimensions of Wildlife, 20, 440-453.

Scheufele, D. A., \& Tewksbury, D. (2007). Framing, agenda setting and priming: The evolution of three media effects models. Journal of Communication, 57(1), 9-20.

Schweinsberg, S., Darcy, S., \& Cheng, M. (2017). The agenda setting power of news media in framing the future role of tourism in protected areas. Tourism Management, 62, 241252.

Showkat, N. (2016). Coverage of sanitation issues in India. SAGE Open, 1-6.

Sodangi, M., Khamidi, M. F., \& Idrus, A. (2013). Maintenance management challenges for heritage buildings used as royal museums in Malaysia. Journal of Applied Sciences and Environmental Sustainability, 1(1), 23-28.

Soroka, S. N. (2002). Issue attributes and agenda-setting by media, the public, and policymakers in Canada. International Journal of Public Opinion Research, 14, 264-285. 
The Star. (2008). George Town and Malacca receive world heritage site award. The Star.

Timothy, D. J. (2018). Making sense of heritage tourism: Research trends in a maturing field of study. Tourism Management Perspectives, 25, 177-180.

Tinch, R., Balian, E., Carss, D., de Blas, D. E., Geamana, N. A., Heink, U., Keune, H., Nesshöver, C., Niemelä, J., Sarkki, S., \& Thibon, M. (2018). Science-policy interfaces for biodiversity: Dynamic learning environments for successful impact. Biodivers. Conserv. 27(7), 16791702.

UNESCO. (2017). Official website. Retrieved from https://ich.unesco.org/en/home World Tourism Organization. News from the World Tourism Organization. (WTO) Retrieved from http://www.world-tourism.org/newsroom/ Releases/morereleases/june2002/data.htm

Woon, P. P., Chatterjee, B., \& Cordery, C. J. (2019). Heritage reporting by Australian public sector: Possibilites from the concept of new public governance. Accounting, Auditing \& Accountability Journal, 32(2), 612-631.

Yang, L. F., \& Ishak, M. A. S. (2011). Framing controversy over language policy in Malaysia: The coverage of PPSMI reversal (teaching of mathematics and science in English) by Malaysian newspapers. Asian Journal of Communication, 22(5), 449-473

Yang, L. F., \& Ishak, M. A. S. (2012). Framing interethnic conflict in Malaysia: A comparative analysis of newspapers coverage on the Hindu Rights Action Force (HINDRAF). International Journal of Communication, 6(24). 166-189. 